\title{
GMR
}

\section{Effects of choice of month of treatment and parity order on bovine superovulation traits}

\author{
Q. Deng ${ }^{1,2 *}$, Y. Gao ${ }^{1 *}$, C.H. Li ${ }^{1,3 *}$, X.F. Yu ${ }^{1}$, J.S. Ren ${ }^{1}$, S.J. Li ${ }^{4}$, C.Z. Chen ${ }^{1}$, \\ B. Yuan ${ }^{1}$, Y. Ding ${ }^{1}$, H. Jiang ${ }^{1}$ and J.B. Zhang ${ }^{1,5}$ \\ ${ }^{1}$ College of Animal Sciences, Jilin University, Changchun, China \\ ${ }^{2}$ Guangdong and Shenzhen Key Laboratory of Male Reproductive Medicine and Genetics, \\ Peking University Shenzhen Hospital, Shenzhen, China \\ ${ }^{3}$ College of Life Science, Baicheng Normal University, Baicheng, China \\ ${ }^{4}$ Hebei Tianhe Beef Cattle Farming Ltd., Shijiazhuang, China \\ ${ }^{5}$ State \& Local Joint Engineering Laboratory for Animal Models of Human Diseases, \\ Changchun, China
}

*These authors contributed equally to this study.

Corresponding authors: J.B. Zhang / H. Jiang

E-mail: zhangjiabao515@163.com / bear_jh@sohu.com

Genet. Mol. Res. 14 (4): 15062-15072 (2015)

Received July 10, 2015

Accepted October 7, 2015

Published November 24, 2015

DOI http://dx.doi.org/10.4238/2015.November.24.14

ABSTRACT. In this study, the performance of 300 Changbaishan Black cattle treated for superovulation from June to September was evaluated to determine the optimal conditions and herds for bovine embryo production. Data analysis revealed that cattle treated in July and August had higher numbers of available embryos (NAE), M1 embryos (NM1), and total embryos (NTE), as well as a higher percentage of M1 embryos (PM1). The temperature and precipitation observed during July and August were greater than those seen in the other two months; strong correlations were observed between these traits and the choice of month of treatment. In addition, multiparous cattle showed a better performance, higher NTE, NAE, NM1, and PM1 values, higher percentages of available embryos, and a lower percentage of degenerated embryos. The co-efficient correlation analysis showed that the month chosen for the treatment did not affect the 
superovulation traits of nulliparous cattle; however, the choice of the month affected multiparous cattle. Multiparous and nulliparous cattle exhibited many significant differences when treated in July and in August. In addition, the superovulatory traits of multiparous cattle, and not the nulliparous cattle, were strongly correlated to the choice of month of treatment. The results suggested that superovulation is more effective during a period with appropriate environmental temperature and humidity, and that multiparous cattle are more suitable for morula production.

Key words: Superovulation traits; Month of treatment; Parity order; Cattle

\section{INTRODUCTION}

The development of assisted reproduction technologies (ART) such as superovulation, artificial insemination (AI), multiple ovulation and embryo transfer (MOET), and somatic cell nuclear transplantation (SCNT) has contributed to the dissemination of breeds that are at a risk of extinction, an accelerated genetic improvements in animals, and other such animal breeding programs (Meuwissen, 1998).

Although substantial progress has been achieved in animal ART in recent decades, some of these techniques have lower efficiency than expected. Many factors can affect the efficiency of ART in both humans and animals; for example, the variability in hormonal super-stimulation response, nutritional status, and developmental synchrony between the transferred embryo and the recipient female are the most significant factors affecting animal embryo transfer (Spearow and Barkley, 1999; Spearow et al., 1999; Perez et al., 2000; Simoni et al., 2002; de Castro et al., 2003, 2004; Santos et al., 2008).

Superovulation is a major step in the embryo transfer technique, and has been practiced in cattle for more than 60 years. In the past decade, our understanding of ovarian follicular growth has seen considerable progress; in addition, the effects of parity order, age, and gonadotropin reparation on the super-ovulatory response in cattle have been elucidated (Bo et al., 2002; Fortune et al., 2004; Gasser et al., 2006; Malhi et al., 2007; Mossa et al., 2007; Malhi et al., 2008). However, many issues pertaining to this remain controversial.

In this study, we statistically analyzed the production data from 300 cattle to test for possible associations between the efficiency of superovulation and the parity order of the treated cattle and choice of month of treatment, with regard to the temperature, precipitation, and duration of sunshine in the particular month.

\section{MATERIAL AND METHODS}

\section{Animals and superovulatory treatment}

Changbaishan black cattle are beef cattle developed via the hybridization of Japanese black cattle with local cattle. This experiment was conducted from June to September in Jilin, China (127.33E, 43.67N). Prior to the superovulation treatment, Changbaishan Black cattle, including nulliparous (11 to 13 months) and multiparous cattle (24-48 months) were selected by trans-rectal palpation for the absence of gynecological abnormalities; all cattle were placed under the unified management of ad libitum feeding with a special, high-protein, high-energy diet. 
These cattle were treated for superovulation using the protocol provided by the AnBo Embryo Biotech Center (Beijing, China). Superovulation was induced by the 16-day Follicle-Stimulating Hormone (FSH) - CIDR (EAZI Breed ${ }^{T M}$ CIDR (progesterone), cattle insert) -Prostaglandin(PG)Luteinizing Hormone Releasing Hormone (LHRH) (FSH-CIDR-PG-LHRH) method described in the Supplementary material. All animal treatments and protocols were approved by the Animal Experiment Ethical Management Committee at Jilin University.

\section{Semen}

Each cow in estrus received two doses of frozen semen, which was collected using an artificial vagina from a fertile Wagyu bull at intervals of 12 hours. The thawed ejaculate met the minimum criteria of $>70 \%$ morphologically normal sperm and $60 \%$ estimated progressive motility. The ejaculate was extended to $1 \times 10^{8} \mathrm{sperm} / \mathrm{mL}$ with clarified egg yolk-citrate-glycerol.

\section{Embryo recovery}

All embryos and ova were recovered by an experienced technician using a standard nonsurgical uterine flushing technique 6 days after Al. The initial search and evaluation of embryos and ova was performed by a single observer with a stereomicroscope (magnifications: 10x to 70x). The compactness and homogeneity of the cell mass of the recovered viable embryos were analyzed using a microscope (70x magnification), and the cells were assessed as described by Linder and Wright (1983). Briefly, the cells were classified as M1 (morula, Grade 1: embryos with single or small extruded blastomeres comprising less than $15 \%$ of the total cellular material), M2 (morula, Grade 2: large cells or individual blastomeres extruded from the embryonic mass that make up more than $15 \%$ but less than $50 \%$ of the total cellular material), or Blastocoel. Embryos with blastomeres containing nuclei, but too underdeveloped to be considered viable, were classified as degenerate. The ovum was designated as being unfertilized when there was no indication of cleavage, or when all cytoplasmic fragments lacked a nucleus.

\section{Statistical analysis}

All data are presented as the mean \pm standard error of mean (SEM) of the values obtained for all tested cattle in the text and figure legends. The statistical significance of the differences between the groups was determined by an independent $t$-test or one-/two-way analysis of variance (ANOVA), followed by a Fisher's protected least-significant difference post-hoc test, unless otherwise specified in the results or figure legends. Statistical significance was set at $P<0.05$.

\section{RESULTS}

\section{Effect of month of treatment}

The superovulation treatment was conducted over a span of four months from June to September, which was thought to be the best season for cattle reproduction in Jilin, China. According to the statistical results (Table 1), cattle had the greatest number of available embryos (NAE, 10.01 $\pm 0.750)$ in August, which was higher than that observed in September $(P<0.05)$, with no significant 
difference being observed between June and July. In addition, cattle had the highest number of total embryos (NTE, $14.96 \pm 0.915$ ) among the four months in August; the lowest number was observed in September $(10.83 \pm 0.901)$. In fact, the number of M2 embryos in August was twice that ofproduced in September $(P<0.05)$. Cattle treated in August had the highest number of M1 embryos (NM1, 7.97 $\pm 0.701)$, and those treated in June showed the fewest M1 embryos $(5.25 \pm 0.672)$. Cattle had the greatest number and highest percentage of blastocyst embryos in July, and the fewest $(0.08 \pm 0.041)$ and lowest percentage (2.95 $\pm 0.51 \%$ ) (of blastocysts) in September. The percentage of M1 embryos (PM1, $43.68 \pm 3.82 \%)$ in June differed significantly from that seen in July $(59.17 \pm 3.97 \%, P<0.05)$, August $(65.41 \pm 2.92 \%, P<0.01)$, and September $(60.23 \pm 3.55 \%, P<0.01)$.

Table 1. Superovulation performances are different among the four months. The values represent the mean \pm SEM.

\begin{tabular}{lcccc}
\hline & June & July & August & September \\
\hline NUE & $1.84 \pm 0.359$ & $1.99 \pm 0.283$ & $1.47 \pm 0.307$ & $1.53 \pm 0.237$ \\
PUE & $16.52 \pm 2.83$ & $14.52 \pm 2.02$ & $9.13 \pm 1.93$ & $16.23 \pm 2.58$ \\
NDE & $2.63 \pm 0.389$ & $3.19 \pm 0.357$ & $3.48 \pm 0.436$ & $2.51 \pm 0.336$ \\
PDE & $21.94 \pm 2.62$ & $23.48 \pm 2.27$ & $21.94 \pm 2.33$ & $22.74 \pm 2.64$ \\
NAE & $8.07 \pm 0.902^{\mathrm{ab}}$ & $9.25 \pm 0.819^{\mathrm{ab}}$ & $10.01 \pm 0.750^{\mathrm{a}}$ & $6.79 \pm 0.745^{\mathrm{b}}$ \\
PAE & $61.65 \pm 0.0367$ & $63.87 \pm 4.00$ & $68.93 \pm 2.88$ & $7.97 \pm 0.701^{\mathrm{b}}$ \\
NM1 & $5.25 \pm 0.672^{\mathrm{a}}$ & $7.19 \pm 0.710^{\mathrm{ab}}$ & $65.41 \pm 2.92^{\mathrm{B}}$ & $5.52 \pm 0.614^{\mathrm{ab}}$ \\
PM1 & $43.68 \pm 3.82^{\mathrm{aA}}$ & $59.17 \pm 0.03 .97^{\mathrm{b}}$ & $1.56 \pm 0.202^{\mathrm{ab}}$ & $6.23 \pm 3.55^{\mathrm{B}}$ \\
NM2 & $2.33 \pm 0.292^{\mathrm{a}}$ & $1.39 \pm 0.221^{\mathrm{ab}}$ & $0.48 \pm 0.185^{\mathrm{ab}}$ & $1.19 \pm 0.235^{\mathrm{b}}$ \\
NBE & $0.48 \pm 0.155^{\mathrm{ab}}$ & $0.68 \pm 0.193^{\mathrm{a}}$ & $3.52 \pm 1.26^{\mathrm{ab}}$ & $0.08 \pm 0.041^{\mathrm{b}}$ \\
PBE & $2.80 \pm 0.80^{\mathrm{ab}}$ & $4.69 \pm 1.32^{\mathrm{a}}$ & $14.96 \pm 0.915^{\mathrm{a}}$ & $2.95 \pm 0.51^{\mathrm{b}}$ \\
NTE & $12.52 \pm 1.100^{\mathrm{ab}}$ & $14.33 \pm 0.902^{\mathrm{a}}$ & $22.10 \pm 0.87^{\mathrm{ab}}$ & $10.83 \pm 0.901^{\mathrm{b}}$ \\
Tm & $19.90 \pm 1.16^{\mathrm{a}}$ & $23.37 \pm 0.38^{\mathrm{b}}$ & $3.93 \pm 0.68^{\mathrm{a}}$ & $14.43 \pm 1.00^{\mathrm{c}}$ \\
PP & $2.56 \pm 0.95^{\mathrm{ab}}$ & $3.55 \pm 0.78^{\mathrm{a}}$ & $7.61 \pm 0.91$ & $0.78 \pm 0.23^{\mathrm{b}}$ \\
ASD & $7.40 \pm 0.70$ & $6.76 \pm 0.40$ & $8.06 \pm 1.00$ \\
\hline
\end{tabular}

NUE = numbers of unfertilized embryos; NDE = numbers of degenerated embryos; NAE = numbers of available embryos; $\mathrm{NM} 1$ = numbers of $\mathrm{M} 1 \mathrm{embryos} ; \mathrm{NBE}=$ numbers of blastulas; $\mathrm{PUE}=$ percentage of unfertilized embryo $=\mathrm{NUE} / \mathrm{NTEx} 100 \%$; $\mathrm{PDE}=$ percentage of degenerated embryo $=\mathrm{NDE} / \mathrm{NTEx} 100 \% ; \mathrm{PAE}=$ percentage of available embryo $=(\mathrm{NM} 1+\mathrm{NM} 2+\mathrm{NBE}) /$ NTEx100\%; PM1 =percentage of M1 embryo $=(\mathrm{NM} 1+\mathrm{NBE}) / \mathrm{NTEx} 100 \% ; \mathrm{PBE}=$ percentage of blastulas rate $=\mathrm{NBE} /$ NTEx $100 \%$; NTE = numbers of total embryos. $\mathrm{Tm}=$ average temperature $\left({ }^{\circ} \mathrm{C}\right) ; \mathrm{PP}=$ average precipitation $(\mathrm{mm}) . \mathrm{ASD}=$ average sunshine duration (hours). ${ }^{a, b}$ Values with different superscripts in the same column differ significantly $(P<0.05)$. $A, B$ Values with different superscripts in the same column differ extremely significantly $(P<0.01)$.

It was much hotter in July $\left(23.37^{\circ} \pm 0.38^{\circ} \mathrm{C}\right)$ and August $\left(22.10^{\circ} \pm 0.87^{\circ} \mathrm{C}\right)$ than in the other months; in addition, the precipitation was greater in July. We observed no differences in the duration of sunshine between these months.

The coefficient of determination represents the percentage of data that is the closest to the line of best fit. The $R$ value indicates the percentage of total variation in $y$ that can be explained by the linear relationship between $x$ and $y$ (described by the regression equation). As shown in Figure 1, the R coefficients for numbers of available embryos (NAE), and total embryos (NTE) with average temperature are 0.915 and 0.939 , respectively, and the regression rates are even higher with the PP. This indicates an almost perfect increase in the linear relationship $(R=1)$ between the NAE and NTE with the environmental factors in the month of treatment.

\section{Effect of the parity order}

The total number of multiparous and nulliparous cattle were 116 and 184, respectively. Many significant multiparous and nulliparous differences were revealed in the whole study by the 
$t$-test. As shown in Table 2, the NTE in multiparous cattle was $14.44 \pm 0.580$, which was higher than that of nulliparous cows $(11.83 \pm 0.503, \mathrm{P}<0.05)$. We observed no differences in the number or percentage of unfertilized ova (PUE). The percentage of degenerated embryos (PDE) in the nulliparous cattle was significantly higher $(0.263 \pm 0.0141)$ than that in the multiparous cows $(0.197$ $\pm 0.0139 ; P<0.01$ ). The number of blastocyst embryos (NBE) did not differ between the two groups of cattle; however, the percentage of blastocyst embryos (PBE) was approximately 2.14 percent higher in the nulliparous cattle. The number and percentage of available and M1 embryos were significantly different between the two groups of cattle, as shown in Table 2.

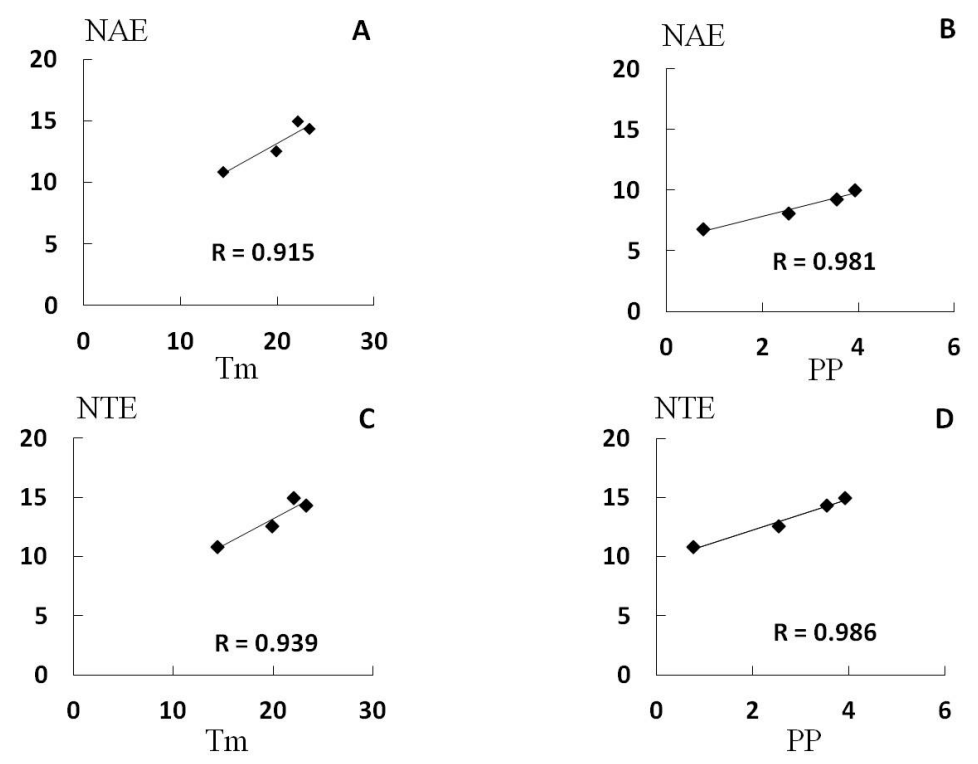

Figure 1. Correlation between superovulation traits and choice of month of treatment.

\begin{tabular}{|c|c|c|}
\hline Superovulation traits & Nulliparous & Multiparous \\
\hline NTE & $11.83 \pm 0.503^{\mathrm{a}}$ & $14.44 \pm 0.580^{b}$ \\
\hline NUE & $1.73 \pm 0.206$ & $1.67 \pm 0.208$ \\
\hline NDE & $3.18 \pm 0.253$ & $2.58 \pm 0.287$ \\
\hline NAE & $7.32 \pm 0.457^{\mathrm{A}}$ & $10.46 \pm 0.733^{\mathrm{B}}$ \\
\hline NM1 & $5.35 \pm 0.380^{A}$ & $8.28 \pm 0.614^{B}$ \\
\hline NBE & $0.52 \pm 0.113$ & $0.29 \pm 0.096$ \\
\hline PUE & $14.43 \pm 1.53$ & $13.58 \pm 1.91$ \\
\hline PDE & $25.55 \pm 1.64^{\mathrm{A}}$ & $17.72 \pm 1.76^{\mathrm{B}}$ \\
\hline PAE & $60.06 \pm 2.10^{A}$ & $69.91 \pm 3.11^{\mathrm{B}}$ \\
\hline PM1 & $53.29 \pm 2.16^{a}$ & $63.20 \pm 3.24^{b}$ \\
\hline PBE & $3.78 \pm 0.76^{a}$ & $1.64 \pm 0.55^{b}$ \\
\hline
\end{tabular}




\section{Co-efficient of parity order and month of treatment}

Three hundred cattle were treated by a super-ovulatory process over four months (75 per month). The parity order and environmental factors in the month of treatment were statistically analyzed using the raw data.

As shown in Table 3, nulliparous and multiparous cattle showed no differences in any of the traits in September, and only exhibited a significant difference in the rate of degenerated embryos $(P<0.05)$ in June. Nulliparous cattle showed a higher PBE $(P<0.05)$ and NBE $(P<0.05)$ compared to multiparous cows, but a lower NAE $(P<0.05)$, NM1 $(P<0.01)$, and $P M 1(P<0.05)$ in July. In August, multiparous cattle showed a better performance in the NAE $(P<0.05)$, NMI $(P<$ $0.05)$, RAE $(P<0.05)$, and PM1 $(P<0.05)$.

\begin{tabular}{|c|c|c|c|c|c|c|c|c|}
\hline & \multicolumn{2}{|c|}{ June } & \multicolumn{2}{|c|}{ July } & \multicolumn{2}{|c|}{ August } & \multicolumn{2}{|c|}{ September } \\
\hline & Nulliparous & Multiparous & Nulliparous & Multiparous & Nulliparous & Multiparous & Nulliparous & Multiparous \\
\hline NTE & $11.326 \pm 1.407^{\mathrm{AB}}$ & $14.414 \pm 1.737^{\mathrm{ab}}$ & $13.196 \pm 1.097^{\mathrm{AB}}$ & $16.138 \pm 1.517^{\mathrm{a}}$ & $13.957 \pm 1.201^{\mathrm{A}}$ & $16.552 \pm 1.379^{\mathrm{a}}$ & $10.413 \pm 1.145^{\mathrm{B}}$ & $11.483 \pm 1.475^{b}$ \\
\hline NUE & $1.674 \pm 0.525$ & $2.103 \pm 0.419$ & $1.978 \pm 0.377$ & $2.000 \pm 0.427$ & $1.783 \pm 0.432$ & $0.966 \pm 0.392$ & $1.478 \pm 0.288$ & $1.621 \pm 0.413$ \\
\hline NDE & $3.403 \pm 0.545$ & $1.966 \pm 0.502$ & $3.435 \pm 0.489$ & $2.793 \pm 0.502$ & $3.565 \pm 0.548$ & $3.345 \pm 0.728$ & $2.696 \pm 0.437$ & $2.207 \pm 0.526$ \\
\hline NAE & $6.630 \pm 0.960$ & $10.345 \pm 1.706^{\mathrm{ab}}$ & $7.783 \pm 0.853^{*}$ & $11.586 \pm 1.553^{\mathrm{ab} *}$ & $8.609 \pm 0.872^{*}$ & $12.241 \pm 1.274^{\mathrm{a}^{*}}$ & $6.239 \pm 0.951$ & $7.655 \pm 1.202^{b}$ \\
\hline NM1 & $4.239 \pm 0.786^{\mathrm{A}}$ & $6.828 \pm 1.162^{\mathrm{ab}}$ & $5.348 \pm 0.620^{\mathrm{AB} * \star}$ & $10.103 \pm 1.403^{\mathrm{a} \star \star}$ & $6.783 \pm 0.825^{\mathrm{B} *}$ & $9.862 \pm 1.188^{\mathrm{a} *}$ & $5.022 \pm 0.767^{\mathrm{AB}}$ & $6.310 \pm 1.020^{b}$ \\
\hline NBE & $0.500 \pm 0.188^{\mathrm{AB}}$ & $0.448 \pm 0.270$ & $0.978 \pm 0.294^{A *}$ & $0.103 \pm 0.103^{\star}$ & $0.457 \pm 0.265^{\mathrm{AB}}$ & $0.517 \pm 0.236$ & $0.0652 \pm 0.0482^{\mathrm{B}}$ & $0.103 \pm 0.0760$ \\
\hline PUE & $14.8 \pm 3.6$ & $19.3 \pm 04.6^{\mathrm{a}}$ & $14.9 \pm 2.60$ & $13.9 \pm 3.27^{\mathrm{ab}}$ & $12.0 \pm 2.90$ & $4.54 \pm 1.72^{\mathrm{b}}$ & $16.0 \pm 3.12$ & $16.6 \pm 4.56^{\mathrm{a}}$ \\
\hline PDE & $26.3 \pm 3.72^{\star}$ & $15.1 \pm 2.99^{*}$ & $25.8 \pm 2.84$ & $19.8 \pm 3.71$ & $24.3 \pm 3.01$ & $18.1 \pm 3.62$ & $25.8 \pm 3.53$ & $17.8 \pm 3.79$ \\
\hline PAE & $59.2 \pm 4.75$ & $65.6 \pm 5.79$ & $59.3 \pm 4.07$ & $71.1 \pm 8.00$ & $63.7 \pm 3.53^{*}$ & $77.3 \pm 4.58^{*}$ & $58.2 \pm 4.47$ & $65.6 \pm 6.07$ \\
\hline PM1 & $43.5 \pm 5.10^{A}$ & $44.0 \pm 5.76^{a}$ & $51.9 \pm 3.75^{\star \mathrm{AB}}$ & $70.7 \pm 7.97^{\star \mathrm{b}}$ & $60.5 \pm 3.61^{\star \mathrm{B}}$ & $73.2 \pm 4.63^{\star \mathrm{b}}$ & $57.2 \pm 4.39^{\mathrm{B}}$ & $65.0 \pm 5.97^{b}$ \\
\hline PBE & $3.68 \pm 1.19^{\mathrm{AB}}$ & $1.40 \pm 0.81^{\mathrm{ab}}$ & $7.37 \pm 2.05^{\star A}$ & $0.45 \pm 0.45^{\star a}$ & $3.13 \pm 1.67^{\mathrm{B}}$ & $4.15 \pm 1.91^{b}$ & $0.94 \pm 0.67^{\mathrm{B}}$ & $0.58 \pm 0.42^{\mathrm{a}}$ \\
\hline
\end{tabular}

NUE = numbers of unfertilized embryos; NDE = numbers of degenerated embryos; NAE = numbers of available embryos; NM1 = numbers of M1 embryos; NBE = numbers of blastulas; PUE = percentage of unfertilized embryo = NUE/NTEx100\%; PDE $=$ percentage of degenerated embryo $=$ NDE/NTEx100\%; PAE $=$ percentage of available embryo $=(\mathrm{NM} 1+\mathrm{NM} 2+\mathrm{NBE}) / \mathrm{NTEx} 100 \% ; \mathrm{PM} 1=$ percentage of $\mathrm{M} 1$ embryo $=(\mathrm{NM} 1+\mathrm{NBE}) / \mathrm{NTEx} 100 \% ; \mathrm{PBE}=$ percentage of blastulas rate $=$ NBE/NTEx $100 \%$. ${ }^{a, b}$ Values with different superscripts in the same column differ significantly in multiparous cattle $(P<0.05)$. ${ }^{A}, B$ Values with different superscripts in the same column differ significantly in nulliparous cattle $(P<0.05)$. Bold data with star superscripts $\left(^{*}\right)$ in one month of the same traits differ significantly $(P<0.05)$, with additional underlining and double star superscripts indicating highly significant differences $(P<0.001)$.

Nulliparous and multiparous cows performed differently during different months. Nulliparous cattle had the highest NTE in August $(13.957 \pm 1.201)$ and the lowest in September $(10.413 \pm 1.145, P<0.05)$; in addition, these cattle exhibited the highest NBE $(0.978 \pm 0.294)$ in July and the lowest in September $(0.0652 \pm 0.0482, P<0.01)$. Nulliparous cattle had a better PM1 in August and September, than in June $(P<0.01$ and $P<0.05$, respectively), and a better $P B E$ in July than in August $(P<0.05)$ and September $(P<0.01)$.

Multiparous cattle showed a better NTE in July (16.138 \pm 1.517$)$ and August (16.552 \pm 1.379), than that in September $(11.483 \pm 1.475)(P<0.05$ and $P<0.05$, respectively). They displayed a lower PUE value in August $(4.54 \pm 1.72)$ than in June $(19.3 \pm 4.6, P<0.01)$ and September $(16.6 \pm 4.56, P<0.05)$. Multiparous cattle showed the lowest PM1 in June $(44.0 \pm 5.76)$, compared to that in the other months (all $P<0.01$ ). Finally, multiparous cattle showed the highest PBE (4.15 \pm 1.91$)$ in August $(P<0.05)$, compared to July and September.

As shown in Figure 2, an almost perfect positive linear relationship was observed between NTE/NAE and the environmental factors in the month of treatment in multiparous cattle, with a 
strong positive linear relationship between NM1 and Tm/PP. However, the regression analysis revealed that the nulliparous cattle only had a strong positive linear relationship $(R>+0.7)$ between NTE and Tm/PP (Figure 3), with a majority of the regression rate being moderate $(R>+0.5)$ or even lower (data not shown).
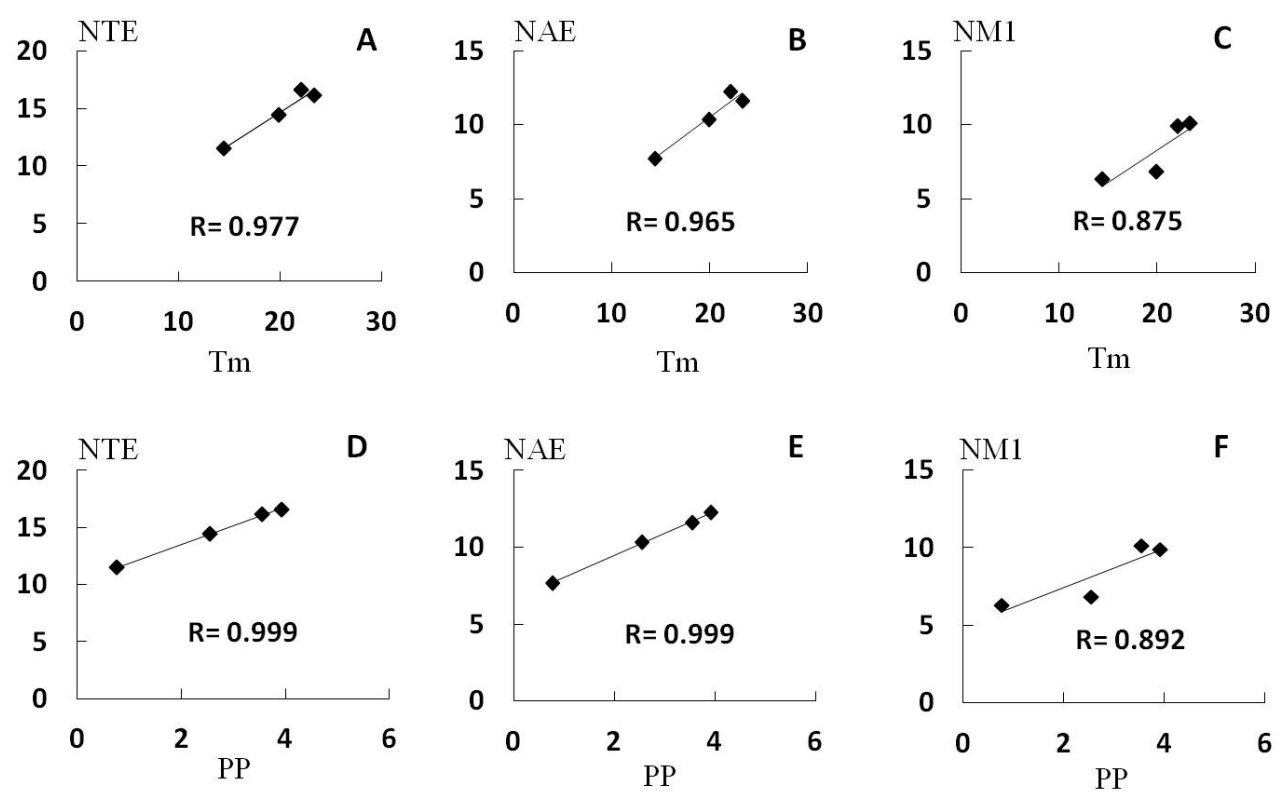

Figure 2. Correlation between superovulation traits and choice of month of treatment in multiparous cattle
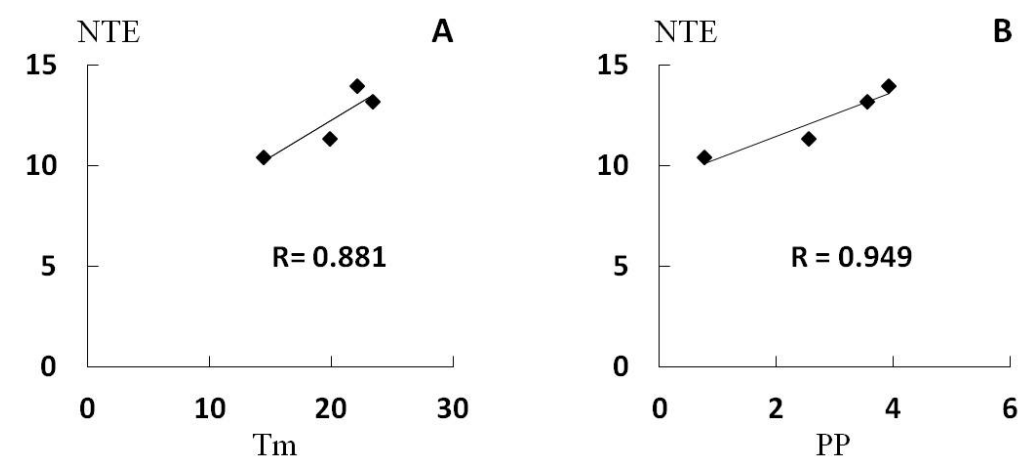

Figure 3. Correlation between superovulation traits and choice of month of treatment in nulliparous cattle.

\section{DISCUSSION}

The wide variability in the superstimulatory response of donor cattle to MOET remains an enigma, and a major limitation in the profitable and efficient implementation of embryo technology in cattle (Keller and Teepker, 1990; Kafi and McGowan, 1997). It has been suggested that the superovulatory response is not a heritable trait, that a future response cannot be predicted by 
a previous response, and that "environmental" factors play a major role in the variability of the superovulatory response (Tonhati et al., 1999).

\section{Effect of choice of month of treatment}

With respect to the natural agricultural production, several reports have indicated that the season had an important effect on superovulation. Hasler (1983) and Lerner et al. (1986) reported the influence of the season on the superovulatory response, while others did not find a consistent seasonal effect on the ovarian response (Massey, 1984; Shea, 1984).

The results of our study showed that the superovulation traits were different during these months, supporting Lerner's theory. Cattle treated in August and July had a greater number of available and M1 embryos, and a strong positive correlation between the traits; in addition, the temperature/precipitation suggested that the choice of the month selected for the treatment does affect the superovulatory response.

The land in Jilin, China is covered with snow for almost 7 months a year. The land would not have thawed by May. Therefore, only four months are suitable for embryo production. However, the temperature between June and September will never rise enough to cause a heat stress effect on animal reproduction. It was reported that high temperatures decrease the oocyte maturation and reduces the number of embryos that cleave into two cells (Lenz et al., 1983; Rivera and Hansen, 2001). Heat stress was also reported to negatively affect the fertilization and embryonic development both in vitro and in vivo (Al-Katanani et al., 2002; Sartori et al., 2002; Hansen, 2007; Edwards et al., 2009); however, another study indicated no change during the summer (Ryan et al., 1993).

Cerri et al. (2009a,b,c) reported that the season affected the embryo development and number. Our data (Table 1) clearly indicated that a temperature of $23.4^{\circ} / 22.1^{\circ} \mathrm{C}$ and a precipitation of $3.55 / 3.93 \mathrm{~mm}$ was more suitable for superovulation treatment than the conditions observed in June $\left(19.9^{\circ} \mathrm{C}\right.$ and $\left.2.56 \mathrm{~mm}\right)$ or September $\left(14.4^{\circ} \mathrm{C}\right.$ and $\left.1.0 \mathrm{~mm}\right)$. This suggested that an appropriate temperature and humidity gave a better response to the superovulation treatment. This data may assist in the future application of superovulation treatment and other assisted reproduction technologies.

\section{Effect of the parity order}

Previous studies reported that the increasing parity did not affect the embryo recovery (ER) or transferable embryo (TE) content (Donaldson, 1984; Lerner et al., 1986; Hasler, 1992), although a large-scale parity order analysis could not be undertaken in Korea (Lee et al., 2012). However, Gebeyehu (2007) found that the parity order was significantly higher $(P<0.01)$ for days open and the calving interval. Cows in their first parity required 35 and 30 more days than the average for days open and calving interval, respectively. However, the effects of parity were not determined for individual farms.

Our studies showed that almost all aspects of the performance of multiparous cattle were better than those of nulliparous cattle. According to statistical analyses, the superovulation traits of nulliparous cattle were not as steady as those of multiparous cows; in addition, a polarization effect was observed among the individual nulliparous cattle.

As shown in Table 2, the parity order had an important effect on some superovulation traits. The statistical results may also provide some actual reference for the selection of donor cattle. With respect to the number of embryos, multiparous cattle showed significantly higher numbers of NTE 
(2.6-fold), NAE, and NM1 (1.5-fold greater) than nulliparous cattle ( $P<0.01$ each). Although we observed no significant differences in the NDE and NUE, the nulliparous cattle showed a higher PDE and PUE $(P<0.01)$, which is consistent with the lower percentage of available embryos.

\section{Coefficient of parity order and month chosen for treatment}

The multiparous cattle showed a very strong positive linear relationship between the trait and month chosen for treatment (Figures 2 and 3); in addition, the number of total and available embryos increased with the PP and Tm. However, nulliparous cattle did not appear to be very sensitive to environmental changes. The NAE and NMI did not increase, despite an increase in the NTE. Almost all of the significant differences between the two groups of cattle were observed in July and August (Table 3), when a better performance was observed compared to the other two months.

Sartori et al. (2010) attributed the reduced number of embryos in heifers to a lower superovulatory response, rather than a reduction in embryo quality, which could be a result of lower FSH doses. Therefore, the poor superovulation performance of nulliparous cattle may be attributed to FSH-insensitivity and stress-sensitivity, or stress non-resistance. The follicle development process in nulliparous cattle was not as complete as that in multiparous cattle. Therefore, the FSH dose could be increased and all stress could be lowered or avoided completely in nulliparous donors.

In conclusion, the superovulation treatment was studied in 300 cattle at a local cattle farm from June to September 2011. The superovulation performance was found to be better in multiparous than in nulliparous cattle. The months with differing temperatures or humidity also had a strong effect on the superovulation response. Further observations are required to determine if the parity order affects the developmental competence of the same embryo stage.

\section{Conflicts of interest}

The authors declare no conflict of interest.

\section{ACKNOWLEDGMENTS}

Research supported by the earmarked fund for Modern Agro-industry Technology Research System (CARS-38), the Key Program for Science and Technology Development of Jilin Province (\#20140204077NY), the program of IRT1248, Science and Technology R \& D Project of Shijiazhuang City, China (\#141500427A), and Cooperative Extension Specialist, Jilin Province Beef Cattle Industrial Technology System. The authors thank the staff for their technical assistance during the superovulation treatments at the Hebei Tianhe Beef Cattle Farming Ltd and cattle breeding farm.

\section{Supplementary material}

\section{REFERENCES}

Al-Katanani YM, Paula-Lopes FF and Hansen PJ (2002). Effect of season and exposure to heat stress on oocyte competence in Holstein cows. J. Dairy Sci. 85: 390-396.

Bo GA, Baruselli PS, Moreno D, Cutaia L, et al. (2002). The control of follicular wave development for self-appointed embryo transfer programs in cattle. Theriogenology 57: 53-72.

Cerri RL, Juchem SO, Chebel RC, Rutigliano HM, et al. (2009a). Effect of fat source differing in fatty acid profile on metabolic parameters, fertilization, and embryo quality in high-producing dairy cows. J. Dairy Sci. 92: 1520-1531. 
Cerri RL, Rutigliano HM, Chebel RC and Santos JE (2009b). Period of dominance of the ovulatory follicle influences embryo quality in lactating dairy cows. Reproduction 137: 813-823.

Cerri RL, Rutigliano HM, Lima FS, Araujo DB, et al. (2009c). Effect of source of supplemental selenium on uterine health and embryo quality in high-producing dairy cows. Theriogenology 71: 1127-1137.

de Castro F, Ruiz R, Montoro L, Perez-Hernandez D, et al. (2003). Role of follicle-stimulating hormone receptor Ser680Asn polymorphism in the efficacy of follicle-stimulating hormone. Fertil. Steril. 80: 571-576.

de Castro F, Moron FJ, Montoro L, Galan JJ, et al. (2004). Human controlled ovarian hyperstimulation outcome is a polygenic trait. Pharmacogenetics 14: 285-293.

Donaldson LE (1984). Cattle breed as a source of variation in embryo transfer. Theriogenology 23: 1013-1018.

Edwards JL, Bogart AN, Rispoli LA, Saxton AM, et al. (2009). Developmental competence of bovine embryos from heatstressed ova. J. Dairy Sci. 92: 563-570.

Fortune JE, Rivera GM and Yang MY (2004). Follicular development: the role of the follicular microenvironment in selection of the dominant follicle. Anim. Reprod. Sci. 82-83: 109-126.

Gasser CL, Burke CR, Mussard ML, Behlke EJ, et al. (2006). Induction of precocious puberty in heifers II: advanced ovarian follicular development. J. Anim. Sci. 84: 2042-2049.

Gebeyehu G, Kelay B and Abebe B (2007). Effect of parity, season and year on reproductive performance and herd life of Friesian cows at Stella private dairy farm Ethiopia. Livest. Res. Rural Dev. 19.

Hansen PJ (2007). To be or not to be-determinants of embryonic survival following heat shock. Theriogenology 68: S40-S48.

Hasler JF (1992). Current status and potential of embryo transfer and reproductive technology in dairy cattle. J. Dairy Sci. 75 : 2857-2879.

Hasler JF, McCauley AD, Schermerhorn EC and Foote RH (1983). Superovulatory response of Holstein cows. Theriogenology 19: 83-99.

Kafi M and McGowan MR (1997). Factors associated with variation in the superovulatory response of cattle. Anim. Reprod. Sci. 48: 137-157.

Keller DS and Teepker G (1990). Effect of variability in response to superovulation on donor cow selection differentials in nucleus breeding schemes. J. Dairy Sci. 73: 549-554.

Lee W, Song K, Lim K, Lee S, et al. (2012). Influence of factors during superovulation on embryo production in Korean Holstein cattle. J. Vet. Med. Sci. 74: 167-174.

Lenz RW, Ball GD, Leibfried ML, Ax RL, et al. (1983). In vitro maturation and fertilization of bovine oocytes are temperaturedependent processes. Biol. Reprod. 29: 173-179.

Lerner SP, Thayne WV, Baker RD, Henschen T, et al. (1986). Age, dose of FSH and other factors affecting superovulation in Holstein cows. J. Anim. Sci. 63: 176-183.

Lindner GM and Wright Jr RW (1983). Bovine embryo morphology and evaluation. Theriogenology 20: 407-416.

Malhi PS, Adams GP, Mapletoft RJ and Singh J (2007). Oocyte developmental competence in a bovine model of reproductive aging. Reproduction 134: 233-239.

Malhi PS, Adams GP, Mapletoft RJ and Singh J (2008). Superovulatory response in a bovine model of reproductive aging. Anim. Reprod. Sci. 109: 100-109.

Massey JM and Oden AJ (1984). No seasonal effect on embryo donor performance in the southwest region of the U.S.A. Theriogenology 21: 196-217.

Meuwissen TH (1998). Optimizing pure line breeding strategies utilizing reproductive technologies. J. Dairy Sci. 81: 47-54.

Mossa F, Duffy P, Naitana S, Lonergan P, et al. (2007). Association between numbers of ovarian follicles in the first follicle wave and superovulatory response in ewes. Anim. Reprod. Sci. 100: 391-396.

Perez Mayorga M, Gromoll J, Behre HM, Gassner C, et al. (2000). Ovarian response to follicle-stimulating hormone (FSH) stimulation depends on the FSH receptor genotype. J. Clin. Endocrinol. Metab. 85: 3365-3369.

Rivera RM and Hansen PJ (2001). Development of cultured bovine embryos after exposure to high temperatures in the physiological range. Reproduction 121: 107-115.

Ryan DP, Prichard JF, Kopel E and Godke RA (1993). Comparing early embryo mortality in dairy cows during hot and cool seasons of the year. Theriogenology 39: 719-737.

Santos JE, Cerri RL and Sartori R (2008). Nutritional management of the donor cow. Theriogenology 69: 88-97.

Sartori R, Sartor-Bergfelt R, Mertens SA, Guenther JN, et al. (2002). Fertilization and early embryonic development in heifers and lactating cows in summer and lactating and dry cows in winter. J. Dairy Sci. 85: 2803-2812.

Sartori R, Bastos MR and Wiltbank MC (2010). Factors affecting fertilisation and early embryo quality in single- and superovulated dairy cattle. Reprod. Fertil. Dev. 22: 151-158.

Shea BF, Janzen RE and McDermand DP (1984). Seasonal variation in response to stimulation and related embryo transfer procedures in Alberta over a nine year period. Theriogenology 21: 186-195. 
Simoni M, Nieschlag E and Gromoll J (2002). Isoforms and single nucleotide polymorphisms of the FSH receptor gene: implications for human reproduction. Hum. Reprod. Update 8: 413-421.

Spearow JL and Barkley M (1999). Genetic control of hormone-induced ovulation rate in mice. Biol. Reprod. 61: 851-856.

Spearow JL, Nutson PA, Mailliard WS, Porter M, et al. (1999). Mapping genes that control hormone-induced ovulation rate in mice. Biol. Reprod. 61: 857-872.

Tonhati H, Lobo RB and Oliveira HN (1999). Repeatability and heritability of response to superovulation in Holstein cows. Theriogenology 51: 1151-1156. 